www.jmscr.igmpublication.org

Impact Factor 5.244

Index Copernicus Value: 5.88

ISSN (e)-2347-176x ISSN (p) 2455-0450

crossref DOI: _http://dx.doi.org/10.18535/jmscr/v4i4.26

\title{
Across Sectional Study on Thyroid Profile in Type II Diabetes Mellitus (Original Article)
}

\author{
Authors \\ Rajhounsh V ${ }^{1}$, Dilip M Rampure ${ }^{2}$, L Suresh Kumar ${ }^{3}$, Santhosh Kumar Cheekoti ${ }^{4}$ \\ ${ }^{1}$ Assistant professor, Dept of General Medicine, Mamata Medical College \& General Hospital, Khammam- \\ 507002, Telangana State \\ ${ }^{2}$ Professor and Head, Dept of General Medicine, Mamata Medical College \& General Hospital, Khammam- \\ 507002, Telangana State. \\ ${ }^{3}$ Post Graduate, Dept of General Medicine, Mamata Medical College \& General Hospital, Khammam- \\ 507002, Telangana State. \\ ${ }^{4}$ Post Graduate, Dept of General Medicine, Mamata Medical College \& General Hospital, Khammam-
} 507002, Telangana State.

\begin{abstract}
Background \& Objectives: Diabetes Mellitus (DM) is a common endocrine disorder which involves multiple organ systems and leads to significant morbidity and mortality due to accompanying complications. DM has been defined as A METABOLIC SYNDROME characterized by chronic hyperglycemia \& disturbance in carbohydrate, fat, protein metabolism with absolute or relative deficiency in insulin secretion or insulin action. There are macro and micro vascular complications of diabetes involving kidneys, eyes, blood vessels, nerves and heart. Thyroid diseases are also a common endocrinopathy seen in adult population.

Thyroid hormones are intimately involved in cellular metabolism. Thus excess or deficit of either insulin or thyroid hormones could result in functional derangement of cellular metabolism. This study would be an attempt to study the prevalence of thyroid disorders in patients with type II diabetes.

Materials \& Methods: This cross sectional study included 100 patients with type II diabetes without previous thyroid abnormalities after meeting inclusion criteria during Jan 2015 to June 2015 held at Mamata Medical College \& General Hospital- Khammam, TS state.

Results: Out of 100 patients with type II DM, 14 had abnormal thyroid profile of which 13 had subclinical hypothyroidism, 1 patient had overt hypothyroidism, $61 \%$ were females, more among those with duration up to 5 years $(68 \%)$.

Conclusion: The prevalence of thyroid dysfunction is more common among type II DM patients than in general population. The prevalence is higher in females than in males.

Key Words: Type II Diabetes Mellitus (DM), Metabolicsyndrome, Subclinical hypothyroidism.
\end{abstract}

\section{INTRODUCTION}

Diabetes mellitus is a group of metabolic diseases characterised by hyperglycemia resulting from defects in insulin secretion, insulin action or both ${ }^{1}$. The chronic hyperglycemia of diabetes is associated with long term damage, dysfunction and failure of various organs, especially the eyes, kidneys, nerves, heart and blood vessels ${ }^{2}$.

Diabetes mellitus is the common endocrine disorder which involves multiple organ systems 
and lead to significant morbidity and mortality due to accompanying complications. The IDF Diabetic Atlas 2012 states that the prevalence of diabetes mellitus is more than 371 millions $^{3}$. Thyroid diseases are the second most common endocrinopathies seen in the adult population. Thyroid hormones are initially involved in cellular metabolism.

The association between these two disorders has long been recognised although the prevalence of thyroid dysfunction in diabetic population varies widely between studies. Withinsulin and thyroid hormone being intimately involved in cellular metabolism and thus excess or deficit of these hormones result in functional derangement of the other.Enhanced sensitivity and specificity of TSH has greatly enhanced assessment of thyroid function.

There are numerous lines of evidence to suggest that type 1DM is an autoimmune disorder. These include the presence of insulitis, presence of antibodies, auto- reactive $\mathrm{T}$ - cells against islet antigens, an association with some other known organ specific autoimmune diseases (thyroid disorders and pernicious anaemia) and a strong association between HLA genes and lastly remission of the disease with immune - modulator therapy. Thus association between thyroid and type 1 diabetics may be auto - immune process ${ }^{4}$.

In euthyroid individuals with diabetes mellitus, the serum T3 levels, basal TSH levels and TSH response to the thyrotropin releasing hormone (TRH)may all be strongly influenced by the glycemic status. Poorly controlled diabetes, both type 1and type 2, may induce a "Low T3 state characterised by low serum total and free $\mathrm{T} 3$ levels, increase in reverse $\mathrm{T} 3(\mathrm{r}$ T3) but near normal serum T4 and TSH concentrations ${ }^{5}$. Low serum T3 is due to reduced peripheral conversion of thyroxine (T4) to tri- iodothyroxine $(\mathrm{t} 3)$ via 5 , monodeiodination reaction and may normalise with improvement in glycemic status but even with good diabetes control, the normal nocturnal TSH peak may not be restored in C-peptide negative patients ${ }^{6}$.
Present study is a modest attempt to study the prevalence of thyroid disorders in patients with type 2 diabetes mellitus.

\section{OBJECTIVES}

To study the prevalence of thyroid disorders in patients with type 2 diabetes mellitus, the distribution of thyroid disorders in regard to their demographic data and to evaluate the relationship between glycemic control and occurrence of altered thyroid function in type 2 diabetes mellitus.

\section{METHODOLOGY}

The present study was carried out in the Department of General Medicine, Mamata Medical College\& General Hospital,Khammam.

1.Study design: Cross sectional study.

2. Period of study: Jan 2015 to June 2015.

3.Materials: Questionnaire, FBS,PLBS, Thyroid profile(FT3,FT4, and TSH), HbA1C.

4.Study group: The study group included 100 patients

\section{Inclusion criteria}

Known type2 diabetes mellitus and newly detected type 2 diabetes mellitus patients who gave an informed consent to participate in the study.

\section{Exclusion criteria}

- Patients not willing for study.

- Patients with known thyroid disease.

- Patients with chronic renal failure and diabetic nephropathy.

- Patients with acute illness (sepsis, acute MI, severe heart failure, recent admission in intensive care unit).

- Patients with hepatic dysfunction.

- Patients with psychiatric illness.

- Pregnancy.

- Patients on treatment with drugs interfering with thyroid function

(Amiodarone, Propranolol, Corticosteroids and Oral contraceptives ${ }^{7}$ ) 


\section{JMSCR Vol||04||Issue||04||Page 10131-10139||April}

All patients in the study group were selected without any bias for sex, duration, severity or control of diabetes. A thorough history was recorded with particular emphasis on symptoms of hypothyroidism and hyperthyroidism. Family history regarding diabetes mellitus and treatment history of oral hypoglycaemics or insulin along with duration was also included.

Blood sugars: Both fasting and postprandial blood sugars are estimated by GOD POD method.

HbA1C:Blood sample collected in EDTA coated tubes and HbAIC is estimated by Biorad- HPLC

method.

Table1. ADA Criteria for the diagnosis of Diabetes Mellitus

\begin{tabular}{|l|}
\hline Symptoms of diabetes plus random blood glucose concentration $\geq 11.1 \mathrm{mmol} / \mathrm{L}(200 \mathrm{mg} / \mathrm{dl})$ \\
\hline Fasting plasma glucose $\geq 7.0 \mathrm{mmol} / \mathrm{L}(126 \mathrm{mg} / \mathrm{dl})$ or \\
\hline Hb1A1C $>6.5 \%$ or \\
\hline Two hour plasma glucose $\geq 11.1 \mathrm{mmol} / \mathrm{L}(200 \mathrm{mg} / \mathrm{dl})$ during an oral glucose tolerance test \\
\hline
\end{tabular}

The patients on antidiabetic therapy were also considered as having diabetes mellitus ${ }^{4}$.

Thyroid profile Reference values:

- TSH : $0.34-4.25$ ? IU $/ \mathrm{ml}$

- FT4 : $0.7-1.24 \mathrm{ng} / \mathrm{dl}$

- FT3 : $2.4-4.2 \mathrm{pg} / \mathrm{ml}$

Overt hypothyroidism is defined as TSH> 5.5 ? IU/ml with FT4<0.7ng/dl.

Subclinical hypothyroidism is defined as TSH> 5? IU/ml with normal FT3 and FT4 levels.
Thyroid Profile:Methods used:

1. TSH - Ultrasensitive sandwich chemi luminescent immuno assay

2. FT3 \&FT4 - Competitive chemi luminescent immune assay.

\section{DEFINITIONS}

Diabetes Mellitus: The WHO in consultation with an expert committee of the American Diabetes Association has approved the following diagnostic criteria for diabetes mellitus, which was used to diagnose new cases.

Table2. Distribution Of Cases According To Type Of Treatment

\begin{tabular}{|c|c|c|}
\hline TYPE OF TREATMENT & NO OF CASES & PERCENTAGE \\
\hline OHA & 78 & $78 \%$ \\
\hline INSULIN & 15 & $15 \%$ \\
\hline BOTH & 07 & $7 \%$ \\
\hline TOTAL & 100 & $100 \%$ \\
\hline
\end{tabular}

Table3.Distribution Of Cases According To Family History Of Diabetes Mellitus

\begin{tabular}{|c|c|c|}
\hline Family H/O DM & No Of Cases & Percentage \\
\hline Yes & 39 & 39 \\
\hline No & 61 & 61 \\
\hline Total & 100 & 100 \\
\hline
\end{tabular}

Table 4.Distribution Of Cases According To Abnormal Thyroid Function

\begin{tabular}{|c|c|c|}
\hline Thyroid Fuction & No. Of Cases & Percentage \\
\hline Normal & 86 & 86 \\
\hline Abnormal & 14 & 14 \\
\hline Total & 100 & 100 \\
\hline
\end{tabular}

Out of 14 patients with abnormal thyroid profile, all the 14 patients (100\%) were aged between 41-60 years. Compared to normal thyroid profile group it has no statistical significance. 
Table 5. Abnormal thyroid profile versus age group

\begin{tabular}{|c|c|c|c|c|}
\hline \multirow{2}{*}{$\begin{array}{l}\text { AGE GROUPS } \\
\text { (Yrs) }\end{array}$} & & \multicolumn{2}{|c|}{ Abnormal Thyroid Profile } & \multirow[t]{2}{*}{ Total } \\
\hline & & No & Yes & \\
\hline \multirow{3}{*}{ Upto 40} & Count & 6 & 0 & 6 \\
\hline & $\begin{array}{l}\% \text { within abnormal } \\
\text { Thyroid profile }\end{array}$ & $7 \%$ & 0 & $6 \%$ \\
\hline & $\%$ of total & $6 \%$ & 0 & $6 \%$ \\
\hline \multirow{3}{*}{$41-60$} & Count & 60 & 14 & $74 \%$ \\
\hline & $\begin{array}{l}\% \text { within abnormal } \\
\text { Thyroid profile }\end{array}$ & $69.8 \%$ & $100 \%$ & $74 \%$ \\
\hline & $\%$ of the total & $60 \%$ & $14 \%$ & $74 \%$ \\
\hline \multirow[t]{3}{*}{$>60$} & Count & 20 & 0 & 20 \\
\hline & $\begin{array}{c}\% \text { within abnormal } \\
\text { Thyroid profile }\end{array}$ & $23.2 \%$ & 0 & $20 \%$ \\
\hline & $\%$ of total & $20 \%$ & 0 & $20 \%$ \\
\hline \multirow[t]{3}{*}{ Total } & Count & 86 & 14 & 100 \\
\hline & $\begin{array}{c}\text { \% within abnormal } \\
\text { Thyroid profile }\end{array}$ & $100 \%$ & $100 \%$ & $100 \%$ \\
\hline & $\%$ of total & $86 \%$ & $14 \%$ & $100 \%$ \\
\hline
\end{tabular}

Table 6. Abnormal thyroid profile Vs. Sex

\begin{tabular}{|c|c|c|c|c|}
\hline \multirow[t]{2}{*}{ Sex } & & \multicolumn{2}{|c|}{ Abnormal Thyroid Profile } & \multirow[t]{2}{*}{ Total } \\
\hline & & No & Yes & \\
\hline \multirow{3}{*}{ Male } & Count & 38 & 1 & 39 \\
\hline & $\begin{array}{ccc}\% & \text { within } & \text { abnormal } \\
\text { thyroid profile } & \\
\end{array}$ & $44.2 \%$ & $7.1 \%$ & $39 \%$ \\
\hline & $\%$ of total & $38 \%$ & $1 \%$ & $39 \%$ \\
\hline \multirow[t]{3}{*}{ Female } & Count & 48 & 13 & 61 \\
\hline & $\begin{array}{l}\% \text { within abnormal thyroid } \\
\text { profile }\end{array}$ & $55.8 \%$ & $92.9 \%$ & $61 \%$ \\
\hline & $\%$ of total & $48 \%$ & $13 \%$ & $61 \%$ \\
\hline \multirow[t]{3}{*}{ Total } & Count & 86 & 14 & 100 \\
\hline & $\begin{array}{c}\% \text { within abnormal } \\
\text { thyroid profile }\end{array}$ & $100 \%$ & $100 \%$ & $100 \%$ \\
\hline & $\%$ of total & $86 \%$ & $14 \%$ & $100 \%$ \\
\hline
\end{tabular}

CHI SQUARE VALUE $=5.47 \quad$ P VALUE $=0.0193$ Significant

Out of the 14 patients with abnormal thyroid profile, $7.1 \%$ (1) was male and $92.9 \%$ were females. Compared with normal thyroid profile group, this was statistically significant.

Table 7.Distribution Of Cases According To Abnormal Thyroid Function

\begin{tabular}{|l|c|c|}
\hline Thyroid Profile & No.Of Cases & Percentage \\
\hline Normal & 86 & 86 \\
\hline Hypothyroidism & 1 & 1 \\
\hline Sub Clinical Hypo & 13 & 13 \\
\hline Hyperthyroidism & 0 & 0 \\
\hline Sub Clinical Hyper & 0 & 0 \\
\hline Total & 100 & 100 \\
\hline
\end{tabular}


Table 8. Abnormal thyroid profile Vs Duration of Diabetes Mellitus

\begin{tabular}{|c|c|c|c|c|}
\hline \multirow{2}{*}{$\begin{array}{c}\text { Duration of } \\
\text { DM (yrs) }\end{array}$} & & \multicolumn{2}{|c|}{ Abnormal Thyroid Profile } & \multirow[t]{2}{*}{ Total } \\
\hline & & No & Yes & \\
\hline \multirow[t]{3}{*}{ Upto 5 yrs } & Count & 58 & 10 & 68 \\
\hline & $\begin{array}{l}\% \text { within abnormal thyroid } \\
\text { profile }\end{array}$ & $67.4 \%$ & $71.4 \%$ & $68 \%$ \\
\hline & $\%$ of total & $58 \%$ & $10 \%$ & $68 \%$ \\
\hline \multirow[t]{3}{*}{$6-10$} & Count & 17 & 4 & 21 \\
\hline & $\begin{array}{l}\% \text { within abnormal thyroid } \\
\text { profile }\end{array}$ & $19.8 \%$ & $28.6 \%$ & $21 \%$ \\
\hline & $\%$ of total & $17 \%$ & $4 \%$ & $21 \%$ \\
\hline \multirow[t]{3}{*}{$>10$} & Count & 11 & 0 & 11 \\
\hline & $\begin{array}{l}\% \text { within abnormal thyroid } \\
\text { profile }\end{array}$ & $12.8 \%$ & 0 & $11 \%$ \\
\hline & $\%$ of total & $11 \%$ & 0 & $11 \%$ \\
\hline \multirow[t]{3}{*}{ Total } & Count & 86 & 14 & 100 \\
\hline & $\begin{array}{l}\% \text { within abnormal thyroid } \\
\text { profile }\end{array}$ & $100 \%$ & $100 \%$ & $100 \%$ \\
\hline & $\%$ of total & $86 \%$ & $14 \%$ & $100 \%$ \\
\hline
\end{tabular}
CHI SQUARE VALUE $=2.26$
P VALUE $=0.323$
Not Significant

Out of the 14 patients with abnormal thyroid profile,71.4\%(10/14)and duration of diabetes 5 years or less, $28.6 \%$ had duration between 6-10 years. Compared with normal thyroid profile group, this was statistically significant.

Table 9. Abnormal thyroid profile Vs type of treatment

\begin{tabular}{|c|c|c|c|c|}
\hline Treatment & No of pt's & Thyroid disorders & Sub clinical hypo & Hypothyroid \\
\hline OHA & 78 & 11 & 10 & 1 \\
\hline INSULIN & 15 & 2 & 2 & 0 \\
\hline OHA'S and Insulin & 7 & 1 & 1 & 0 \\
\hline
\end{tabular}
CHI SQUARE $=2.14$
$P$ value $=0.293$
Not significant

Out of the 14 patients with abnormal thyroid profile, $78.6 \%(11 / 14)$ were on OHA, $14.3 \%(2 / 14)$ were on insulin $\& 7.1 \%$ (1/14) on both OHA \& insulin. Compared with normal thyroid profile group, this was not statistically significant.

Table 10. Abnormal thyroid profile Vs Family history of Diabetes Mellitus

\begin{tabular}{|l|l|l|l|l|}
\hline \multirow{2}{*}{$\begin{array}{c}\text { Family } \\
\text { history }\end{array}$} & & \multicolumn{2}{|c|}{ Abnormal } & \multirow{2}{*}{ Total } \\
\cline { 3 - 5 } & & profile & Yes & \\
\hline \multirow{3}{*}{ No } & Count & 50 & 61 & 11 \\
\cline { 2 - 5 } & $\%$ within abnormal thyroid profile & 58.15 & $78.6 \%$ & $61 \%$ \\
\cline { 2 - 5 } & $\%$ of total & $50 \%$ & $11 \%$ & $61 \%$ \\
\hline \multirow{3}{*}{ Yes } & Count & 36 & 3 & 39 \\
\cline { 2 - 5 } & $\%$ within abnormal thyroid profile & $41.9 \%$ & $21.4 \%$ & $39 \%$ \\
\cline { 2 - 5 } & $\%$ of total & $36 \%$ & $3 \%$ & $39 \%$ \\
\hline \multirow{3}{*}{ Total } & Count & 86 & 14 & 100 \\
\cline { 2 - 5 } & $\%$ within abnormal thyroid profile & $100 \%$ & $100 \%$ & $100 \%$ \\
\cline { 2 - 5 } & $\%$ of total & $86 \%$ & $14 \%$ & $100 \%$ \\
\hline
\end{tabular}

CHI SQUARE VALUE $=1.34 \quad$ P VALUE $=0.247 \quad$ NotSignificant


Out of the 14 patients with abnormal thyroid profile, $21.4 \%(3 / 14)$ had family history of diabetes mellitus, $78.6 \%$ (11/14) had no family history. Compared with normal thyroid profile group, this was not statistically significant.

Table 11. Abnormal Thyroid profile Vs HbA1c level

\begin{tabular}{|c|c|c|c|c|}
\hline \multirow[t]{2}{*}{ HbA1c level } & & \multicolumn{2}{|c|}{ Abnormal Thyroid Profile } & \multirow[t]{2}{*}{ Total } \\
\hline & & No & Yes & \\
\hline \multirow[t]{3}{*}{$<7 \%$} & Count & 28 & 5 & 33 \\
\hline & $\begin{array}{l}\% \text { within abnormal thyroid } \\
\text { profile }\end{array}$ & $32.6 \%$ & $35.7 \%$ & $33 \%$ \\
\hline & $\%$ of total & $28 \%$ & $5 \%$ & $33 \%$ \\
\hline \multirow{3}{*}{$>7 \%$} & Count & 58 & 9 & 67 \\
\hline & $\begin{array}{l}\% \text { within abnormal thyroid } \\
\text { profile }\end{array}$ & $67.4 \%$ & $64.3 \%$ & $67 \%$ \\
\hline & $\%$ of total & $58 \%$ & $9 \%$ & $67 \%$ \\
\hline \multirow[t]{3}{*}{ total } & Count & 86 & 14 & 100 \\
\hline & $\%$ within abnormal T. profile & $100 \%$ & $100 \%$ & $100 \%$ \\
\hline & $\%$ of total & $86 \%$ & $14 \%$ & $100 \%$ \\
\hline
\end{tabular}

CHI SQUARE VALUE $=0.01 \quad$ P VALUE $=0.9203 \quad$ Not Significant

Out of 14 patients with abnormal thyroid profile, 64.3\% (9/14) had HbAlc value above 7 and the remaining $35.7 \%(5 / 14)$ had HbA1c 7 or less. Compared with normal thyroid profile group, this was not statistically significant.

\section{DISCUSSION}

A total of 100 type 2 diabetics were studied.

\section{AGE DISTRIBUTION}

In the present study of 100 type 2diabetic patients, 6 patients $(6 \%)$ were upto 40 years, 74 patients (74\%) were between 41-60 years and 20 patients (20\%) were 61 years or more. This shows that the disease was more prevalent between 41-60 years of age.

This observation was similar to IDF ATLAS, 2012 report which states that the greatest numbers of people with type 2 diabetes mellitus are between 40-59 years of age. This observation was also similar to WHO report ${ }^{3}$. Which predicts that while the main increase in diabetes would be in the $>65$ years age group in the developed countries, in India and developing countries the highest increase would occur in the age group of 45-65 years of age group. This observation is also similar to Kapur et al, who reported that maximum numbers of cases were diagnosed between 40 and 59 years of age with no significant difference between the genders ${ }^{9}$.

\section{GENDER DISTRIBUTION}

In the present study 39\% (39) of the studied population were males and $61 \%$ (61) were females. Female to male ratio was 1.5:1.

This observation was similar to Arthur M. Michalek et al who reported that prevalence of diabetes among women was higher than in men ${ }^{10}$. This is in contrast to Jali et $\mathrm{al}^{11}$ and Flatau E et $\mathrm{al}^{12}$ who reported that diabetes was more prevalent in men than in women.

\section{FAMILY HISTORY OF DIABETES MELLITUS}

In the present study, $39 \%$ of patients had family history of Diabetes and the remaining 61\% had no family history.

This study is similar to that of Tattersal and Fojans $^{13}$ and Vishwanthan ${ }^{14}$. Vishwanathan et al conducted a study on 107 subjects. Out of 73 subjects who gave positive family history 
diabetes, 19 subjects (26\%) later developed diabetes.

\section{HBAIC LEVEL}

In the present study, $67 \%$ patients had $\mathrm{HbA} 1 \mathrm{C}$ level more than $7 \%$ and $33 \%$ had level $\mathrm{HbA} 1 \mathrm{C}$ less than $7 \%$. More than two- thirds of the diabetics had poor glycemic control. Paolo fumelli in his study of 562 diabetic patients found that all the patients had level HbA1C greater than $8 \%{ }^{15}$.

\section{ABNORMAL THYROID PROFILE}

In the present study, $14 \%$ of the patients with diabetes mellitus had abnormal thyroid profile

The present study is similar to Abdel-Rahman et $\mathrm{al}^{16}$ who in his study of 908 type 2 diabetic patients found that the prevalence of thyroid disease was $12.5 \%, 6.6 \%$ of whom were newly diagnosed and $5.9 \%$ had known thyroid dysfunction. The prevalence of thyroid disease in the non diabetic control group was $6.6 \%$.

Chubb et al in a cross-sectional study of 420 patients with type 2 diabetes mellitus found that $8.6 \%$ of patients had subclinical hypothyroidism ${ }^{17}$. D.H.Akbar et al in their study of 100 type 2 diabetics found that the prevalence of thyroid dysfunction was $16 \%$ and in control group of non diabetics, it was $7 \%^{18}$.

Smithson M J in his study found that the prevalence of thyroid disease in the entire population of diabetic patients registered in the general practice was $10.8 \%$. In the control group of non diabetics, the prevalence was $6.6 \%{ }^{19}$.

\section{DISTRIBUTION OF THYROID ABNORMALITIES}

In the present study,13\% (13)of the patients had reports suggestive of sub clinical hypothyroidism and $1 \%$ (1) patient had report suggestive of overt hypothyroidism.

This study was similar to Abdel-Rahman et al who in their study of 908 type 2 diabetic patients found that $10.3 \%$ of patients had hypothyroidism(overt and sub clinical) and $1.7 \%$ of patients had hyperthyroidism (overt and sub clinical $)^{13}$.Smithson et al in their study of 233 diabetes mellitus patients found that 11patients were found to have undiagnosed thyroid disease, out of which 9 were having hypothyroidism(overt and sub clinical) and 2 were having hyperthyroidism(overt and sub clinical) ${ }^{19}$.

Celani MF et al in their study of 290 type2diabetes mellitus patients found that 91 patients(31.4\%) had abnormal TSH concentrations out of which $48.3 \%$ had sub clinical hypothyroidism, $24.2 \%$ had sub clinical hyperthyroidism, $23.1 \%$ had overt hypothyroidism and $4.4 \%$ had overt hyperthyroidism ${ }^{20}$.

\section{SIGNIFICANCE OF AGE IN PATIENTS WITH ABNORMAL THYROID PROFILE}

Among the patients with abnormal thyroid profile, all the patients $(100 \%)$ were aged between 41 to 60 years. Though there is difference, when compared between patients with normal and abnormal thyroid profile it has no significance $(\mathrm{p}=0.057)$.

The present study findings contradict with that of Chubb et al who in their study found that age and anti-TPO status correlates with altered thyroid profile in diabetic patients ${ }^{17}$.

Vondra et al in his study found that thyroid diseases in diabetic patients is 2-3 times higher than in non diabetic subjects; it raises with age, and is strongly influenced by female gender and autoimmune diabetes ${ }^{21}$. This also contradicts with our findings.

\section{ANALYSIS OF SEX DISTRIBUTION IN CAES WITH ABNORMAL THYROID PROFILE}

In the present study $92.9 \%$ (13/14) patients were found to be female compared to $7.1 \%(1 / 14)$ male in the group with abnormal thyroid profile. Compared between patients with normal and abnormal thyroid profile this was statistically significant $(\mathrm{p}=0.0193)$.

Celani MF et al ${ }^{20}$, Arthur M. Michalek et $\mathrm{al}^{10}$ and Abdel - Rahman et $\mathrm{al}^{16}$ in their study found that the prevalence of thyroid dysfunction was 
significantly higher in the female than in the male diabetic patients.

Vondra et $\mathrm{al}^{21}$ found significant correlation between female gender and altered thyroid profile. SIGNIFICANCE OF TYPE OF TREATMENT IN PATIENTS WITH ABNOMAL THYROID PROFILE:

Out of 14 patients with thyroid abnormality, $78.6 \%(11 / 14)$ were on OHA, $14.3 \%$ (2/14) were on insulin and $7.7 \%(1 / 14)$ were on both OHA/Insulin. Compared with normal thyroid profile group it has no statistical significance $(\mathrm{p}=0.293)$

The findings of our study are similar with Chubb et $\mathrm{al}^{17}$, who in their study found that altered thyroid profile was associated with anti- TPO status and age. Celani MF et $\mathrm{al}^{20}$ in their study found that the prevalence of abnormal thyroid function test results was significantly higher in insulin treated patients than in those receiving OHA. This contradicts with our study.

\section{ANALYSIS OF HbA1C LEVEL IN CASES WITH NORMAL AND ABNORMAL THYROID PROFILE}

Out of 14 patients with abnormal thyroid profile, $64.3 \%(9 / 14)$ had HbA1C value above $7 \%$ and the remaining $(35.7 \%)$ had HbA1C 7 or less. The mean $\mathrm{HbA1C}$ level of the patients with abnormal thyroid profile was $8.31 \%$ compared to $7.57 \%$ in the patients with normal thyroid profile. This difference is not statistically significance $(\mathrm{p}=0.228)$.

The findings are similar to Chubb et $\mathrm{al}^{17}$ who found no correlation between changes in free thyroid hormone concentrations and HbA1C level. Celani MF et $\mathrm{al}^{20}$ in their study in 91 diabetic patients with altered thyroid profile found that TSH level in serum decreased in sub clinical hypothyroidism and increased in sub clinical hyperthyroidism with significant fall in $\mathrm{HbA} 1 \mathrm{C}$ level. This contradicts with our findings.

\section{CONCLUSION}

Prevalence of thyroid dysfunction is more common among type 2 diabetes mellitus patients than in general population.

Prevalence of thyroid dysfunction in patients with type 2 diabetes mellitus is higher in females than in males.

Routine screening for thyroid dysfunction in type 2 diabetes mellitus patients may be justified especially in females because the progression to overt thyroid dysfunction is associated with significant morbidity including the adverse effects on glycemic control, lipid profile, bone mineral density and cardiovascular events.

\section{REFERENCES}

1. Peter H. Bennett, William C. Knowlap. Definition, diagnosis and classification of diabetes. Josin's diabetes mellitus $14^{\text {th }}$ edition, 2005: 331-337.

2. Alvin C. Powers. Diabetes mellitus. Harrison's principles of internal medicine $18^{\text {th }}$ edition, 2012: 2968-3003.

3. IDF Diabetes atlas $5^{\text {th }}$ edition, 2012.

4. American Diabetes Association, Standards of medical care in Diabetes-2013. Diabetes Care, Volume 36, Supplement 1, January 2013.

5. Kalmann R, Mourits M. Diabetes Mellitus: a risk factor in patients with Grave's orbitopathy. Br. J. Ophthalmol 1999; 83:463-465.

6. Coiro V, Volpi R, Marchesi C, et al. Influence of residual $\mathrm{C}$-peptide secretion on nocturnal serum TSH peak in wellcontrolled diabetic patients. Clin. Endocrinal. 1997; 47: 305-10.

7. Thyroid and anti thyroid drugs. Katzung Basic clinical pharmacology $10^{\text {th }}$ edition, 2007: 618-634.

8. J. Larry Jameson, Anthony P. Weetman. Disorders of thyroid gland. Harrison's principles of internal medicine, $18^{\text {th }}$ edition, 2012: 2911-2939. 
9. Kapur A, Snehalatha C, Ramachandran A, Vijay V, Mohan V, Das AK, Rao PV, Yajnik C S, Prasanna Kumar K M, Jyotsna Nair: High prevalence of diabetes and impaired glucose tolerance in India. National Urban diabetes survey. Diabetolgia 2001; Vol. 44: 1094-1101.

10. Arthur M. Michalek, Martin C. Mahoney, Donald Calebaugh: Hypothyroidism and Diabetes Mellitus in an American Population. Journal of family practice 2000 July; 49: 638-640.

11. Jali MV, Mohan V, Ramachandran A, Snehalatha C and Vishwanathan M; High prevalence of diabetes in an urban population in South India. BMJ Sep 1988; Vol. 297: 587-590.

12. Flatau E, Trougouboff P, Kaufman N, Reichman N, Luboshitzky R. Prevalence of hypothyroidism and diabetes mellitus in elderly kibbutz members. European Journal of Epidemiology, Volume 16, Number 1, January 2000, 43-46 (4).

13. Tattersal R B, Fojans S, Arbor A: Prevalence of Diabetes and Glucose Intolerance in offsprings of 37 conjugal diabetic parents. Diabetes 1975, 24: 452462.

14. Vishwanathan M, Mohan V, Snehalatha C, Ramachandran A. High prevalence of type 2 diabetes among the offspring of conjugal type 2 parents in India. Diabetolgia, 1985, 28: 907-910.

15. Paolo Fumelli, Silvia Natalucci, Massimo Boemi. One and two compartment minimal models detect similar alterations of glucose metabolism indexes in hypertension. Metabolism, Volume 49; 12: 1529-1536.

16. Abdel Rahman, Nusier M K, Amari F L et al. Thyroid dysfunction in patients with type 2 Diabetes mellitus in Jordan. Saudi Med J. 2004 Aug 25 (8): 1046-50.
17. Chubb SA, Davis WA, Inman Z, Davis D $M$ E. Prevalence and progression of subclinical hypothyroidism in women with type 2 diabetes: The Fremantle diabetes study. ClinEndrocrinol (Oxf). 2005 Apr; 62 (4): 480-6.

18. Akbar D H, Ahmed MM, Al-MughalsJ. Thyroid dysfunction and thyroid auto immunity in Saudi type 2 diabetics. Acta Diabetologica. 2006 May; 43(1): 14-18.

19. Smithson MJ. Screening for thyroid dysfunction in a community population of diabetic patients. Diabet Med 1998; 15 (2): 148-50.

20. Celani MF, Bonati ME, Stucci N. Prevalence of abnormal thyrotropin concentrations in measured by a sensitive assay in patients with type 2 diabetes mellitus. Diabetes Res 1994; 27: 15-25.

21. Vondra K, Vrbikova J, Dyorakova K. Thyroid gland diseases in adult patients with diabetes mellitus. Minerva Endrocrinol. 2005 Dec; 30(4):217-36. 